\title{
University of California will stay in charge at weapons labs
}

\section{Berkeley}

For the University of California (UC), operating the Department of Energy (DoE) weapons laboratories at Los Alamos, New Mexico and Livermore, California has been a public relations nightmare. And with the expiration of the law that protected UC from liability claims in the event of an accident at one of the laboratories, operating them threatened to become a financial nightmare as well. But UC Regents believe the service is worth the trouble.

For years, critics have charged that it is inappropriate for a university to be running top-secret facilities primarily devoted to designing and testing nuclear weapons. But William Frazer, UC vicepresident, says if it is national policy to have such facilities, they should be run in as open a manner as possible, something a university is best equipped to do. Despite criticisms, the University decided two years ago that, when the existing 5-year contract with DoE expired, it would seek a renewal.

But that was also two years before the expiry date of the Price Anderson Act. That law was enacted to provide liability protection for the nuclear power industry in the event of an accident at a power plant. But it also contained provisions that indemnified DoE contractors. DoE not only owns its own research reactors, it is also the agency responsible for building nuclear weapons. Contractors say that liability protection is essential to make operating such facilities financially viable.

Last year it seemed that a compromise had been reached permitting the renewal of Price Anderson and raising the limits of liability for nuclear plant operators to levels in line with the cost of an accident (see Nature 322, 676; 1986). But at the eleventh hour, the compromise fell apart, and renewal legislation had to be reintroduced.

For the university, this posed a dilemma. Its contract with DoE expired on $30 \mathrm{Sep}$ - tember, and without liability protection, $\mathrm{UC}$ felt the financial risk was too great to renew the Los Alamos and Lawrence Livermore contracts. So DoE came up with the idea of indemnifying its contractors under Public Law 85-804, part of the War Powers Act. Unlike Price Anderson, the War Powers Act does have a condition in which UC could be liable for damages. But it would take an act of wilful misconduct or bad faith by the laboratory direc-

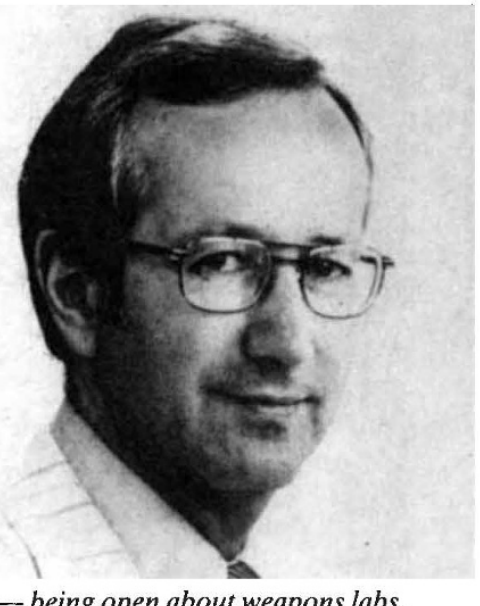

Frazer-being open about weapons labs.

tor or one of his superiors to make UC liable, and then liability extends only to government property. With the guarantees provided by $85-804$, UC and DoE agreed a new five-year contract on 18 September.

But UC officials say the new coverage is a bad deal for the public. UC counsel Glenn Woods explained that the War Powers Act coverage has less protection for claimants seeking damages under Price Anderson.

Other DoE contractors are not sanguine about liability coverage under the War Powers Act. Several say they will not sign future contracts without Price Anderson-type protection. Last month DuPont announced that it would not renew its contract to operate DoE's Savannah River plant where plutonium and tritium are \section{Huge iceberg adrift in \\ Washington}

A CHANGE in the maps of Antarctica will be necessary following the departure of an enormous iceberg, 2,500 square miles in area, from the Ross Ice Shelf. This single iceberg contains two or three times as much ice than breaks off from the Antarctic continent during a typical year. The Bay of Whales, the starting point of many early expeditions, has largely disappeared.

The creation and fate of icebergs is not well understood. As glaciers such as the Ross Ice Shelf run down to the sea, they fragment, and the pieces drift westwards along the coastline. Unless they crash back

\section{Antarctic seas}

into the continent, ocean currents pick them up and they begin to circulate eastwards in the circumpolar flow. Eventually they break up and melt, but large icebergs can survive for many months.

Icebergs in the Southern Hemisphere are not the same threat to shipping as in the north; the icebergs may drift as far in latitude, but southern shipping lanes are much further from the polar regions. The only danger might be to scientific survey ships, but the US Navy and the National Oceanic and Atmospheric Administration will be watching the iceberg's progress carefully.

\section{Efficiency bid by research commission}

\section{Brussels}

As part of a determined effort to increase efficiency in its Joint Research Centre (JRC), which runs laboratories at four separate sites, the European Commission is proposing to split it into nine autonomous institutions. It also wants to abolish the scientific council that oversees the work of the JRC so scientists will have a greater say in the research programmes, and to answer criticisms from members of the European Community (Nature 329, 576; 1987).

A new institute for advanced materials will be established at Petten, in The Netherlands. The Central Bureau for Nuclear Measurements at Geel, Belgium, and the Institute for Transuranium Elements at Karlsrhue West Germany, will remain. The Ispra establishment in Italy will be split into five institutes for engineering, environmental sciences, remote sensing, safety technology, electronics, information technology, and a new European Telecommunications Standards Institute. Research ministers meet this month to discuss the proposals.

Bernard Conlon

produced. DuPont said its decision was based in part on the belief that a growing number of elected officials "favour elimination of protection of liability" crucial for its financial security

Price Anderson's future in Congress is still uncertain. The House of Representatives has passed one version, but it has yet to reach the Senate.

Joseph Palca

The recently signed contract between UC and DoE for running the Los Alamos, Livermore and Lawrence Berkeley laboratories has some sweetners for the university. The fee for operating the facilities will climb from approximately $\$ 7$ million to $\$ 12$ million per year, still a tiny fraction of the nearly $\$ 2,000$ million annual budget for the three facilities. The new money will allow the expansion of university-laboratory collaborations.

UC has argued that DoE has been too restrictive in its approach to allowing patents to vest with contractors at its national laboratories. William DeGarmo, counsel for Lawrence Livermore National Laboratory, says DoE has made it extremely difficult for the laboratory to enter into any commercial arrangements with industry. Instead, he says, DoE has put non-classified inventions and software into the public domain, discouraging industry from investing in it. DeGarmo says commercial development of inventions developed with government money has been a time-honoured and successful way of bringing new technology to the market place. "If DoE had developed the airplane, we wouldn't have commercial aviation", he says. 